\title{
怪骨近位端骨折の治療成績
}

\begin{tabular}{cccc}
\multicolumn{2}{c}{ 九州労災病院整形外科 } & & \\
佐 & 藤 & 護 & 彦 \\
安 & 田 & 博 & 行 \\
加 & 茂 & 洋 & 志
\end{tabular}

\section{End Result Study of Fractures of The tibial Condyle}

By

\author{
M. Sato, H. Yasuda \& H. Kamo \\ Orthopedic Clinic, Kyushu Labour Accidental Hospital
}

緒

言

脛骨近位端骨折はその合併症と相まって非常に治療 困難な骨折である.

近年, 産業, スポーツ, 交通機関の発達に伴い増加 の一途をたどり従来の報告に見るごとく比較的稀な骨 折とい言い難い感がある.

われわれは過去 5 年間に当科にて加療を行った脛骨 近位端骨折の 58 例について機能的予後を中心に 若干 の検討を行ったので報告する.

\section{調 查 対 象}

過去 5 年間に 加療した脛骨近位端骨折の 総数は 58 例で開放性骨折が 23 例, 皮下骨折が 35 例で年令別で は 20 才代が圧倒的に多く, 性別では制性が多数を占 め女性の約 4 倍である.

受傷原因は交通事故によるものが 45 例で多数を占 め近年ますますその比率を高めてくる傾向にある.

骨折型は関節外 24 例, 関節内骨折は 34 例でうちわ けは外顆骨折 8 , 内顆骨折 9 , 両顆骨折 4 , 顆間隆起 骨折 13 であるが受傷機点との 相関関係は受傷時の肢 位が不明なあのが多く明確にし得なかった. しかし近 年上く報告されている dashboard inj. と思われる あのは脛骨後䆟部の骨折と股関節の脱臼を合併した 1 例のでみ水平外力によると思われるものは意外に少な かった.

\section{合併症}

合併症は治療予後に重大な影響を与えるものである が全く合併症のなかったむのはわずか 6 例に過ざず $90 \%$ 以上に何等かの合併を認めた。乙のうち 関節周 辺の軟部組織損傷は勒帯損傷が 7 例で 5 例を手術的に 2 例を保存的に加療したが手術例, 保存療法例の各 1 例に膝動摇をみた. 2 例とも勒帯形成術を施行した. 半月板損傷は 8 例で 5 例は手術時確認したもので他の 3 例は自動運動開始後関節造影にて診断したあのであ る. 全例に meniecotomie を行った.

腓骨神経麻㾇は 7 例でいずれも一次性のものであ る. 5 例に神経剝離術, 1 例に神経縫合を行ったが最 終的に 2 例は回復しなかった.

\section{治療および予後}

関節外骨折は早期運動開始の目的で腓骨々頭骨折, 転位のないむの, 合併症のため手術不能の場合を除い て積極的に手術を行っている.

手術での内固定は screw, hockplate よるものが 多いが他に blade plate, 圧迫プレートによるものも 数例あり plate と screw の併用例むある. 骨移植を 行ったものは 4 例で 2 例は顆下部骨折で整復時大きな 海綿骨の欠損を生じたもので他の 2 例は初診時すでに 偽関節となっていたあのである.

固定期間は平均 7.1 週 であった。

関節内骨折は整復ギプス固定あるいは牽引後ギプス 固定を行い観血的には 図 1 Volt screw にて固定し 


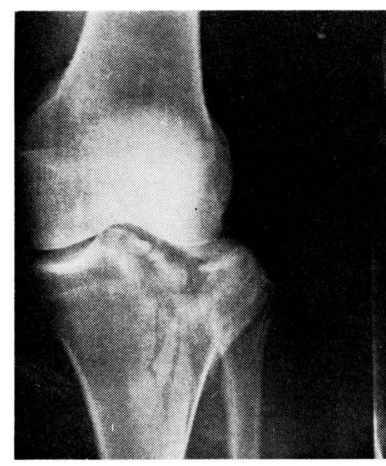

術前

図 1

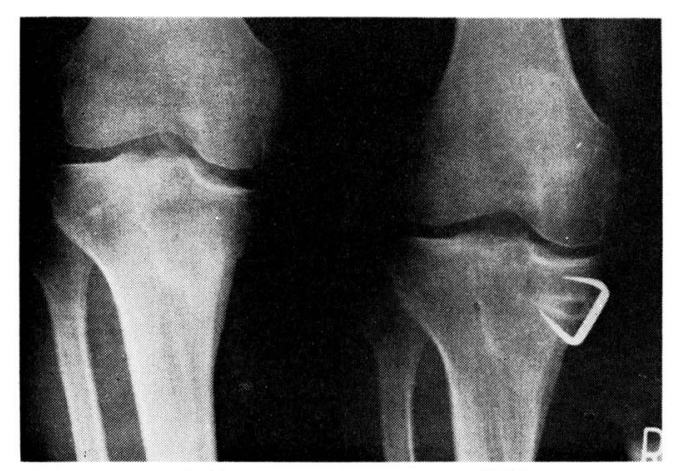

術前

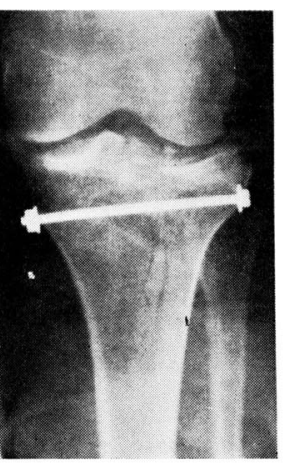

術後

図 2

顆間隆起骨折には wireによるプールアウト法をもっ ぱら行っている.

固定期間は平均 7.7 週を要した。

$$
\text { 予後 }
$$

関節外骨折で保存的療法を行ったものは 13 例で 70
\%は機能障害を残すことなく治癒した.

機能障害を残したものは 4 例でうち 2 例は来院時す でに骨髅炎を併発していたもので 1 例は $165^{\circ}$ 屈曲位 にて強直となり惨めな結果を招いた，他の 2 例は骨癋 合が遷延し固定が長期に変ったあのである.

観血的に加療したものは $82 \%$ が満足すべき成績で あった. 切断の 1 例はガス壊疽を併発したものであ る.

また下腿の内反外反変形を残したものは 2 例で 1 例 は $15^{\circ}$ の内反変形老有し外傷性の関節症を呈して強い 疼痛を訴え跛行が著明であったので変形予防, 疼痛除 去の目的で high tibial osteotory 在行った. 術後 8 週より歩行を開始したが屈曲も $45^{\circ}$ 迄可能で疼痛む 軽減している. 加療に際しては内外反変形に留意すべ きである. 関節内骨折はHohl の分類に從って機能 的予後上解剖学的予後に分けて行った.

結果は表 1 のごよくで㙨能的には $61 \%$, 解剖学的 には $70 \%$ \%゙満足すべき屯のであった.

不可亡なったものば脳挫傷や大腿骨遠位端の粉砕骨折 などの重篤な合併症を有し初期の加療が十分でなかっ 记もの 1 例, 手術時整復術不充分なもの 1 例之骨折片 が loose body となった顆間隆起骨折の 1 例である.

二次的に手術を行ったあのは 1 例で表 3 のごとく内 顆の陷没があり同部に骨硬化を認める, 疼痛が大で原 職に復帰出来ない上訴えるので骨移植を行いプラトウ の棚上げを行った. 現在疼痛なく就労している.

$$
\text { 考按 }
$$

関節外骨折については省略し特に問題の多い関節内 骨折について述べる.

脛骨近位端骨折の病態は多様性走し治療法は病態

\begin{tabular}{|c|c|c|c|c|c|c|c|c|c|}
\hline & & \multicolumn{2}{|c|}{ 機 } & \multicolumn{2}{|c|}{ 的 } & \multicolumn{2}{|c|}{ 解 } & 学 & 的 \\
\hline & & 優 & 良 & 可 & 不可 & 優 & 良 & 可 & 不可 \\
\hline 保 存 的 & $\begin{array}{lll}\text { 外顆 } & \text { 骨 折 } \\
\text { 内 顆 } & \text { 骨 折 } \\
\text { 両 顆 } & \text { 骨 折 } \\
\text { 顆間隆 起 骨折 }\end{array}$ & $\begin{array}{l}2 \\
2 \\
1 \\
5\end{array}$ & $\begin{array}{l}1 \\
1 \\
2 \\
3\end{array}$ & $\begin{array}{l}1 \\
1\end{array}$ & $\begin{array}{l}1 \\
1 \\
2\end{array}$ & $\begin{array}{l}1 \\
2 \\
5\end{array}$ & $\begin{array}{l}2 \\
1 \\
2 \\
4\end{array}$ & $\begin{array}{l}1 \\
1 \\
1\end{array}$ & $\begin{array}{l}1 \\
2\end{array}$ \\
\hline 観 血 的 & $\begin{array}{lll}\text { 外 顆 } & \text { 骨折 } \\
\text { 内 顆 骨 折 } \\
\text { 陑 顆 } \\
\text { 骨 折 } \\
\text { 顆閌隆起骨折 }\end{array}$ & $\begin{array}{l}3 \\
1 \\
1\end{array}$ & $\begin{array}{l}1 \\
2\end{array}$ & 1 & $\begin{array}{l}1 \\
1\end{array}$ & $\begin{array}{l}2 \\
2 \\
3\end{array}$ & 1 & $\begin{array}{l}1 \\
1\end{array}$ & 1 \\
\hline 合 & 計 & 15 & 10 & 3 & 6 & 15 & 10 & 5 & 4 \\
\hline
\end{tabular}

表 1 関節向骨折予後 
構成因子によって細かく検討さるべきであるが，主目 標はあくまで機能障害を最小にすることである。乙れ がためには 1）関節面の解剖学的整復 2) 関節支 持組織の修復 3） 早期運動練習が必要である.

まず転位であるが Hohl は $10 \mathrm{~mm}$ 以上の垂直方向 の転位, $15 \mathrm{~mm}$ 以上の外方転位 打よび部分的陷没を また Rombeld は $5 \mathrm{~mm}$ 以上の垂直方向転位 $10 \mathrm{~mm}$ 以上の水平転位, $5^{\circ}$ 以上の内外反变形を保存的療法 の限界としている.

われわれの今回の調查であ経過年数が短かにかかわ らず垂直方向の転位は外傷性関節症を続発し易い傾向 にある，また慶大の伊勢亀，橋爪などの報告でも 5 $\mathrm{mm}$ 以上の陥没で $80 \%, 10 \mathrm{~mm}$ 以上の楩没では 100 \% Arthrose を呈したとのととで乎術は今少し積極 的に行ってむよいと考えている.

粉础骨折の手術例はほとんよ゙ないので決定的な断定 は出来ないがわれわれは丹念な保存療法が優ると考元 ている.われわれの症例中 $24 \%$ 勒帯損傷を合併し ていたが初期での確実な修復があっとも重要である. 半月板は Hohl や Barr は関節面の整復や充分な観 察のため正常半月板む摘出すべきであると主張してい るが半月板を除去しなくてあ整復はほとんど症例で可 能であり, 正常半月板摘出の必要はないと思う.

運動開始時期は人により術直後よりあるいは遅くて 屯 3 週 よりと主張する者や $7 \sim 9$ 週 後より行うべき であると強調する者むいてその見解にかなり隔りがあ るが，われわれは今回时関節周辺骨折の調査で 8 週 以内で自動運動開始した症例ではほとんど機能障害を 残していないととが判った. われわれは運動開始は関 節支持組織の修復, 骨癒合の点より 5 週 を越えて可 及的に早期に運動開始をするのが適当と思っている.

\section{結}

語

われわれは 今回 58 例の 脛骨近位端骨折について機 能的予後を中心に治療法, 運動開始時期などにつき若 干の検討を行い報告した。

\section{文献}

1) Barr: The Treatment of Fracture of the External Tibial Condyle J. Am. Med. Ass. 115: 1683, 1940.

2) Hohl : J. B. J. S. 38-A : 1001, 1956.

3) Rombald: J. B. J. S. : 42-A : 783, 1955

4) 松井: 中部日本整形外会誌. 11巻, 121 .

5）渡辺 - 他：中部日本整形外会誌. $9: 643$, 昭 41 .

6）前之園 - 他：中部整災誌 $9(3): 647$, 昭 41 .

7) 小谷 勉: 臨床整形外科. 2(2): 185 , 昭 42 .

8) 伊勢龟 - 他: 整形外科. 20(8): 879, 昭44.

9) Böhler : Die Technik der knochenbruchbehardlung 1945.

10) Watson-Jones: Fractured Joint Injuries. 1956.

11）玉井達二：下肢骨折，臨休整形外全書. 2 (1963).

質 問 中国労災整形 平川 宽 解剖学的関係加ら脛骨近位端骨折には血管損傷を合 併したものが 私共の経験では 10 例ほどあり，なかに は顆間隆起骨折で皮下骨折であったにあかかわらず, 膝窩動脈の断裂をみた症例がある．貴院ではいかがで あったか?

解 答 九州労災 佐藤 護彦 58 例中血管損傷は有りませんでした. 